\title{
NICU に拈ける輸血の検討
}

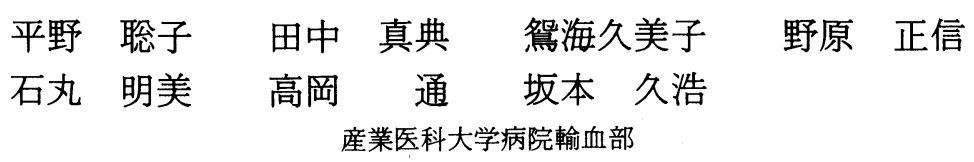

（昭和61年10月24日受付）

\section{BLOOD TRANSFUSION PROGRAM IN NICU}

\author{
Satoko Hirano, Masanori Tanaka, Kumiko Oshinomi, Masanobu Nohara, \\ Akemi Ishimaru, Toru Takaoka and Hisahiro Sakamoto \\ Blood Transfusion Service, University of Occupational and Environmental \\ Health, School of Medicine
}

Transfuion in NICU was studied for the last two years. For extreme premature infants, much less volume of blood was frequently needed and walking donors' blood was used in NICU. However, six cases out of eighty-eight infants were transfused without complete pretransfusion tests and seventeen cases were transfused for more than two months without any recheck. Then, it is safer for infants that the red cross blood center always supply screened blood unit subdivided into two or three satellite bags to be used several times and fresh whole blood for exchange transfusions.

In this study we found three premature infants suffered from GVHD-like syndrome, possibly due to transfusions. Therefore, irradiation has been started on blood for infants.

\section{はじめに}

近年, 新生児医療は目覚しい進歩を遂げてき た ${ }^{122)}$ が, 集中治療のため多くの症例が頻回の輸血 を必要とし，家族，知人などを供血者とする，い わゆる walking donor からの輸血が日常的に行 われている344.

新生児の場合, 1 回輸血量が少ないため, 1 人 の walking donor から繰り返し採血することに より, 供血者数を減らし, 輸血後感染症や同種免 疫の危険性を減少させることができる。ささら緊 急時にも新鮮血を入手しやすく，家族の安心感を 得られるなどの利点を持つ, その反面, 輸血部で の管理が不十分になりやすく, 緊急時には, 未検 查で輸血されたり，輸血が長期間にわたる場合に も, 再検査が行われないなどの欠点を有する5).

そこで我々は, 当院 NICU (neonatal intensive care unit）での新生児, 乳児に対する輸血の現状 を調査しより安全な輸血の在り方について検討 した.

\section{対象と方法}

1984年 1 月より1985年12月までに NICUに入 院した新生児, 乳児220例と, walking donor 271 名を対象とし, 疾患名, 輸血回数, 輸血量, walking donor 検査結果执よび副作用について調査した。 なお追跡期間は1986年 5 月までとした。

\section{結果}

\section{1. 対象症例の疾患名}

対象児220例中, walking donorを準備したの は, 121例 (55\%) であり, そのうち半数を出生体 重2,000 $\mathrm{g}$ 末満の未熟児が占め, 呼吸不全, 感染症, 出血を伴う症例が多かった（表 1 ）.

\section{2. 輸血された症例の割合}

220例中107例（うち 5 例は交換輸血のみ） $49 \%$ が輸血されており, 出生体重別には, $1,000 \mathrm{~g}$ 末満 の超未熟児で $85 \%, 1,500 \mathrm{~g}$ 未満の極小未熟児で $91 \%, 2,000 \mathrm{~g}$ 未満の未熟児で $70 \%, 2,000 \mathrm{~g}$ 以上の 児では $35 \%$ に輸血が行われていた。

3. 輸血回数および輸血量（交換輸血を除く） 
102例に対して721回の輸血が行われた. 出生体 重別の平均輸血回数は, 超未熟児では18.3回（2 ～50回)，極小未熟児では11.7回（1～64回）と頻 回であった。 さらにこれらの症例では, walking donor からの輸血が $90 \%$ を占め, 平均供血者数は, 超未熟児 3.8 人, 極小未熟児 2.8 人之輸血回数に比 べて明らかに少なかった（表 2 ）。

1 回の輸血量は $21 \sim 30 \mathrm{~m} l$ が最も多く, 総輸血 回数の $48 \%$ $30 \mathrm{~m} l$ 以下, $77 \%$ $50 \mathrm{~m} l$ 以下の輸血 であった(図 1 ). 1 回当りの輸血量は平均 $41.7 \mathrm{~m} l$ $(4 \sim 688 \mathrm{~m} l)$ であり, 出生体重別には, 超未熟児 $31.6 \mathrm{~m} l$, 極小未熟児 $32.2 \mathrm{~m} l$, 未熟児 $42.7 \mathrm{~m} l$, $2,000 \mathrm{~g}$ 以上の児では $62.2 \mathrm{ml}$ であった。

表 1 walking donor を準備した症例の疾患名

（重複あり）

\begin{tabular}{l|c|c|l|c|c}
\hline 疾 患 名 & 症例数 & $\%$ & 疾 患 名 & 症例数 & $\%$ \\
\hline 未熟児 & 61 & 50.4 & 新生児仮死 & 18 & 14.9 \\
呼吸不全 & 39 & 32.2 & 黄病 & 16 & 13.2 \\
感染症 & 36 & 29.8 & 消化器疾患 & 15 & 12.4 \\
出血 & 28 & 23.1 & 血液疾患 & 13 & 10.7 \\
心臓疾患 & 19 & 15.7 & 腫瘍 & 6 & 5.0 \\
\hline
\end{tabular}

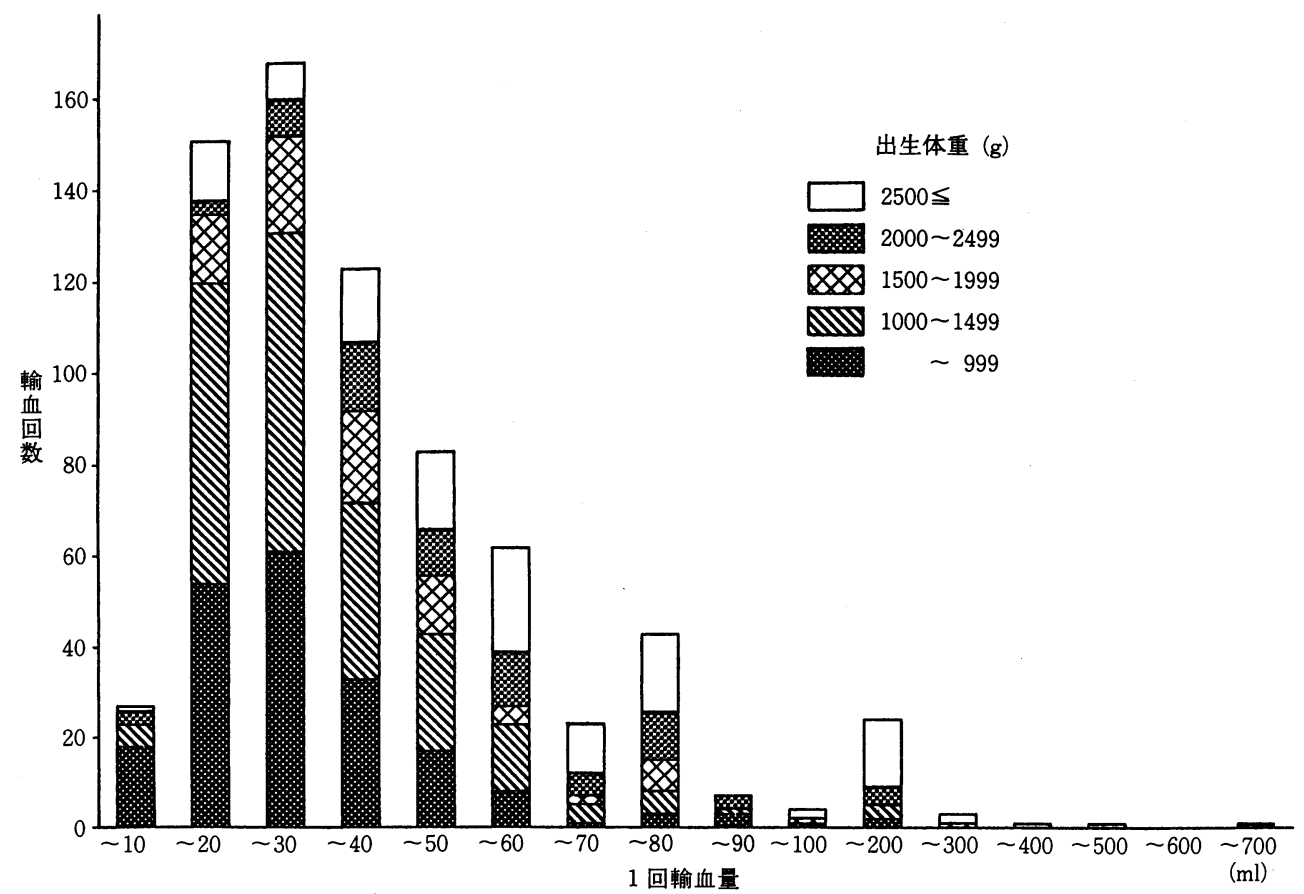

図 1 出生体重, 1 回輸血量別の輸血回数

\section{4. 交換輸血}

23例に対し52回の交換輸血が実施された。 1 回 平均 $325 \mathrm{~m} l$, 合計 $16,900 \mathrm{~m} l$ の血液を使用し，この らち $10,060 \mathrm{~m} l(60 \%)$ が walking donor からの新 鮮血であった。

52回のうち，血液型不適合妊娠によるものは， $\mathrm{ABO}$ 式血液型不適合の 2 例 3 回のみであり, 13 例34回が敗血症やDIC の治療を目的としたもの であった（表 3 ）。

5. walking donor 血液の輸血

対象児のらち, walking donor 血液が輸血され たものは88例であった：輸血部への連絡がなく， 不十分な検査 $(\mathrm{ABO}, \mathrm{Rh}$ 式血液型，クロスマッチ

表 2 平均輸血回数

\begin{tabular}{c|c|c|c}
\hline 出生体重 & 平均輸血回数 & 平均供血者数 & $\begin{array}{c}\text { walking donor } \\
\text { 使用の割合 }\end{array}$ \\
\hline ～999g & 18.3 回 & 3.8 人 & $88.6 \%$ \\
$1000 \sim 1499$ & 11.7 & 2.8 & 90.2 \\
$1500 \sim 1999$ & 3.2 & 2.1 & 64.3 \\
$2000 \sim 2499$ & 4.9 & 4.6 & 57.3 \\
$2500 \leqq$ & 3.6 & 3.1 & 42.5 \\
\hline
\end{tabular}


表 3 交換輸血症例

\begin{tabular}{|c|c|c|c|c|c|}
\hline 疾 患 名 & 症例数 & $\begin{array}{l}\text { 交換輸血 } \\
\text { 数 }\end{array}$ & $\begin{array}{l}\text { 平均交換 } \\
\text { 回 数 }\end{array}$ & $\begin{array}{l}\text { 平均交換 } \\
\text { 量/回 }(\mathrm{m} l)\end{array}$ & $\begin{array}{l}\text { 平均出生 } \\
\text { 体重 }(\mathrm{g})\end{array}$ \\
\hline 敗血症, DIC & 13 & 34 & 2.6 & 300 & 1546 \\
\hline 呼吸窮迫症候群 & 3 & 7 & 2.3 & 284 & 1438 \\
\hline $\begin{array}{l}\text { 高ビリルビン血症 } \\
\text { (血液型不適合妊娠) }\end{array}$ & 2 & 3 & 1.5 & 447 & 2916 \\
\hline $\begin{array}{l}\text { 高ビリルビン血症 } \\
\text { (その他の原因) }\end{array}$ & 5 & 8 & 1.6 & 423 & 2439 \\
\hline 合 計 & 23 & 52 & 2.3 & 325 & $\backslash$ \\
\hline
\end{tabular}

表 4 walking donor 検查不合格の内訳

\begin{tabular}{l|r|r|r}
\hline & \multicolumn{1}{|c|}{ 男 性 } & \multicolumn{1}{c|}{ 女 性 } & \multicolumn{1}{c}{ 合 計 } \\
\hline GPT 31IU/l 以上 & $19(10.1)$ & $3(3.6)$ & $22(8.1)$ \\
貧 血 & $3(1.6)$ & $15(18.1)$ & $18(6.6)$ \\
HBs 抗原陽性 & $5(2.7)$ & $2(2.4)$ & $7(2.6)$ \\
不規則抗体陽性 & \multicolumn{1}{|c|}{0} & $2(2.4)$ & $2(0.7)$ \\
問診不合格 & $4(2.1)$ & $18(21.7)$ & $22(8.1)$ \\
\hline$\frac{\text { 不合格者数 }}{\text { 検查総数 }}(\%)$ & $\frac{31}{188}(16.5)$ & $\frac{34}{83}(41.0)$ & $\frac{65}{271}(24.0)$ \\
\hline
\end{tabular}

のみ主治医が実施）で輸血された症例が 6 例，輸 血部への検査申し込み当日が28例，翌日が12例， 3 日目以降に輸血されたものが42例であった，検 査不十分で輸血された 6 例のらち 4 例は緊急交換 輸血, 1 例は大量出血, 1 例は貧血改善のためで あった。供血者は父親 4 名, 小児科医師 4 名, 看 護婦 1 名であったが，事後検査に拉いて不合格者 はいなかった。

検査日から最終輸血日までの輸血継続期間は, 52例（59\%）が 1 カ月未満, 19例（22\%）が 1 力 月以上 2 カ月未満, 17 例 (19\%) が 2 カ月以上で あり, 最高 8 カ月にわたって, 再検査を行わずに
同一供血者血液を輸血されていた症例も 1 例あっ た。

\section{6. walkding donor 検査結果}

男性供血者の $16.5 \%$ ，女性供血者の $41.0 \%$ ，全 体では $24.0 \%$ が不合格であった。なお女性供血者 の問診不合格者 18 名中14名は, 出産後 6 力月以内 の母親であった（表 4 ）.

7. 副作用

溶血副作用や診断基準6) に該当する輸血後肝炎 は発症していないが，父親の血液を頻回に輸血さ れた後に, 皮疹, 下掓, 肝腫大, 汎血球减少症な ぞ GVHD (graft-versus-host disease) を強く疑 わせる臨床症状を呈して死亡した 3 症例（表 5 ） を経験した。早期新生児死亡（日齢 0 〜日）を 除く死亡症例11例中の 3 例を占め, 出生体重 1,500 $\mathrm{g}$ 未満児の中では, 5 例中の 3 例と高頻度であっ た。しかし，これらの症例については，皮膚生検， HLA タイピングなどの検査が不十分であり，輸 血後 GVHD との確定はできなかった。

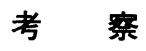

新生児集中治療には，連日頻回の検査採血が必

表 5 GVHD 様症状を呈した3症例

\begin{tabular}{|c|c|c|c|c|c|c|c|c|c|c|c|c|}
\hline \multirow[b]{2}{*}{ 症 例 } & \multirow[b]{2}{*}{ 性別 } & \multirow[b]{2}{*}{$\begin{array}{c}\text { 在 胎 } \\
\text { (週十昌) }\end{array}$} & \multirow[b]{2}{*}{$\frac{\text { 出生体重 }}{(\mathrm{g})}$} & \multirow[b]{2}{*}{$\begin{array}{l}\text { 交 } \\
\text { 換 } \\
\text { 輸 } \\
\text { 血 } \\
\text { (回) }\end{array}$} & \multirow[b]{2}{*}{ WD } & \multirow[b]{2}{*}{$\begin{array}{c}\text { WDよりの } \\
\text { 輸血 } \\
(\mathrm{m} l / \text { 回 })\end{array}$} & \multicolumn{2}{|r|}{ 症 } & \multicolumn{2}{|l|}{ 状 } & \multirow[b]{2}{*}{$\begin{array}{l}\text { 発 } \\
\text { 症 } \\
\text { 日 } \\
\text { 齡 }\end{array}$} & \multirow[b]{2}{*}{$\begin{array}{c}\text { 死 } \\
\text { 亡 } \\
\text { 日. } \\
\text { 齢 }\end{array}$} \\
\hline & & & & & & & 疹 & 下 & $\begin{array}{l}\text { 肝 } \\
\text { 腫 } \\
\text { 大 }\end{array}$ & $\begin{array}{l}\text { 汎 } \\
\text { 血 } \\
\text { 球 } \\
\text { 少 } \\
\text { 症 }\end{array}$ & & \\
\hline 1. $\mathrm{MN}$ & F & $26+4$ & 790 & 0 & 父 & $556 / 18$ & + & + & + & + & 160 & 171 \\
\hline 2. $\mathrm{NY}$ & F & $27+2$ & 1052 & 0 & 父 & $130 / 7$ & + & \pm & + & + & 90 & 96 \\
\hline 3. $\mathrm{RM}$ & F & $30+2$ & 1250 & 4 & 父 & $160 / 11$ & + & + & + & + & 20 & 32 \\
\hline
\end{tabular}

WD : Walking donor 
要78)であり, 出血や溶血がないにもかかわらず, 頻回の輸血を必要とする症例が多くみられる.

当院においても NICU 入院児の $49 \%$ が輸血さ れ, 特に出生体重 $1,500 \mathrm{~g}$ 末満の児では, 高率に頻 回の輸血を必要としており, 後遺症なき生存を期 するためにも，安全な輸血が行われることが不可 欠であると思われた。

現在, 供血者数を减らす目的で, walking donor からの輸血が好んで行われているが, 出生体重 $1,500 \mathrm{~g}$ 以上の児では, 輸血回数が平均 3.7 回と比 較的少なかったことから, walking donor を利用 する効果は小さく，供血者検査済みの日赤血の使 用がより適切であると思われた。

$1,500 \mathrm{~g}$ 未満の児では輸血回数が多く, walking donorの利用により供血者数を輸血回数の 4 分の 1 以下に減らすことができた。しかし，供血者検 查が不十分な walking donor 血液が輸血された 症例や，再検査を行わずに長期間，同一供血者か ら輸血された症例があり, walking donor の不合 格率が $24 \%$ と高率であったこと，また輸血が長期 にわたる場合には，供血者が貧血に陥る恐れがあ ること, 児の免疫能の発達により同種抗体を産生

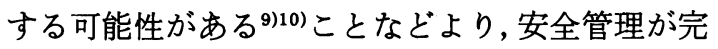
全になされていない場合には, walking donorの 利用は, 供血者, 受血者双方にとって危険性が高 いと思われた。

さらに, HBs 抗原未検查の walking donor 血液 を輸血され劇症肝炎を発症して死亡した症例 ${ }^{11}$ や, 乳幼児, 特に未熟児では輸血による AIDS 発 症の危険性が大きいといら報告 ${ }^{12) 13)}$ もりり, 将来 的に, 発症, キャリア化する可能性を含めて感染 症予防のための検査が特に重要であると思われ た。しかし緊急時に, HBs 抗原, 梅毒, ATLA, HIV 抗体検査等を含めて, 病院輸血部において, 短時間にすべての検査を完了することは，極めて 困難であり，供血者検查済みの日赤血の使用がよ り安全であって，これを促進すべきであると考え られた。

また, NICU における輸血の77\%までが $50 \mathrm{ml}$ 以 下であり, 輸血単位数の増加に伴って感染症の危

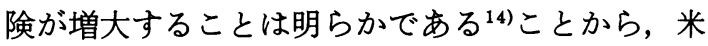

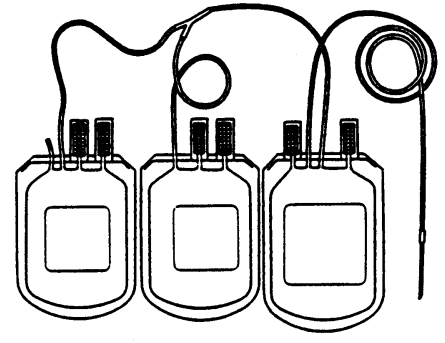

( 3 連バック)

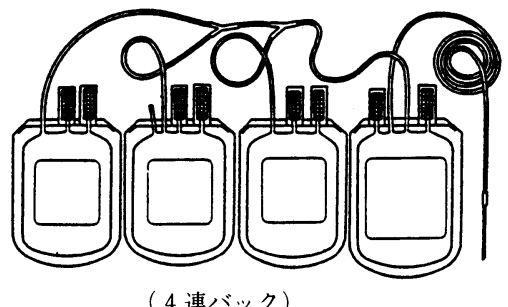

因 2 多連バック

国の一部で行われているよらな，予め小児用に小 分けされた冷凍血液 pediatric frozen red blood cell packs (Pedi-Packs) ${ }^{7 / 8)}$ の利用が我が国に招 いても検討されるべきであると思われた. しかし， 設備, 費用, 解凍後の有効期限が12時間と短いな ぞの欠点が有り, 現時点では, 多連バック（図 2) に採血された日赤血 1 バックを, $50 \mathrm{~m} l$ 程度ずつ に小分けし，数回分として利用できる製剤の供給 が望ましいと考えられた。そこで，当院では，赤 十字血液センターから 3 連バックに採血された新 鮮血の供給を受け，輸血部にて閉鎖的に 3 分割し た製剤の使用を薦めている。

さらに, 交換輸血用血液の60\%が walking donor 血液であったが, 4 例の緊急交換輸血で, 検 査が不十分な血液が使用されていたことから，緊 急時にも，血液センターより速やかに新鮮血が供 給される体制が必要であると思われた。しかし， ATLA, HIV 抗体検查の開始により，検査終了ま での時間が延長し, 小児科医が要求する生血とし ての新鮮血の供給が困難な状態であり, 症例に よっては, 採血後 7 日以内 ${ }^{15)}$, あるいは 4 日以内の 血液でも十分である ${ }^{16)}$ と思われ，新生児に対する 新鮮血の適応を再検討する必要があると考えられ た. 
新生児への輸血による GVHD の報告は少ない が, 期間中, 頻回の輸血後に GVHD 様症状を呈し て死亡した 3 例の極小未熟児を経験した。我が国 に怙いて，新生児が頻回輸血後に GVHDを発症

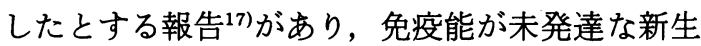
児では十分予想されることから，1986年 7 月より NICU で使用する血液に $1,500 \mathrm{cGy}$ の放射線照射 を実施している，放射線照射血液の輸血後経過に ついては，現在追跡調査中である。

$$
\text { まとめ }
$$

新生児の輸血では, 輸血後感染症や同種免疫を 予防するために，供血者数を減らすことが重要で あり, 出生体重 $1,500 \mathrm{~g}$ 末満の児では, walking donor の利用によって供血者数を減らすことが可 能であった。

しかし，検查不十分な walking donor 血液が輸 血された症例や，再検査を行わずに長期間，同一 供血者から輸血された症例があり，供血者検査済 みの日赤血の使用がより安全であると思われた。

そのためには，小児用として 1 バックを 3 連ま たは 4 連バックに小分けし，数回分として使用で きる日赤血が供給されること，さらに緊急時にも 速やかに日赤新鮮血が供給される体制が不可欠で あると考えられた。

期間中に 3 例の未熟児が GVHD 様症状を呈し て死亡したため，新生児用血液への放射線照射を 開始した。

\section{文献}

1）厚生省大臣官房統計情報部編：昭和59年人口動態 統計上巻. 厚生統計協会, 東京, 1986 .

2）赤松 洋, 宇都宮正司, 川上 義, 曽根良治, 荻 田安時, 常井幹雄 : 死亡率, 主要死因の年次的推 移々新生児医療の評価。小児科臨床, $38: 1507$ $-1518,1985$.

3) Blankenship, W.J., Goetzman, B.W., Gross, S. and Hattersley, P.G.: A walking donor program for an intensive care nursery. J. Pediatr., $86: 583-585,1975$.

4）村田文也, 竹内 徹, 船戸正久, 多田 裕, 三科 潤：極小未熟児の輸血に関する調查成績(その1).
周産期医学, $14 ： 801-808,1984$.

5) Butch, S.H.: Technical aspects of transfusion. In: Hemotherapy of the infant and premature, The committee on technical workshops (eds. Luban N.L.C. and Keating, L.J.). American Association of Blood Banks, Arlington Virginia, 1983, pp. 100-127.

6）片山 透：輸血後非 $\mathrm{A}$ 非 $\mathrm{B}$ 肝炎の診断基準. 日 輸血会誌，31：316-320， 1985 .

7) Kakaiya, R.M., Morrison, F.S., Rawson, J.E., Lotz, L.L. and Martin, J.W.: Pedi-pack transfusion in a newborn intensive care unit. Transfusion, 19: 19-24, 1979.

8) $\operatorname{Mex} \phi$, E., Cristensen, N.C. and Olesen, H.: Volume of blood removed for analytical purposes during hospitalization of low-birthweight infants. Clin. Chem., 27 : 759-761, 1981.

9) Smith, M.R. and Storey, C.G.: Allo-anti-E in an 18-day-old infant. Transfusion, $24: 540,1984$.

10）村田文也, 竹内 徹, 船戸正久, 多田 裕, 三科 潤：極小末熟児の輸血に関する調査成績 (その2). 周産期医学, $14: 921-928,1984$.

11) Kakaiya, R.M., Morrison, F.S., Halbrook, J.C., Rawson, J.E. and Lotz, L.L. : Problems with a walking donor transfusion program. Transfusion, 19: 577-580, 1979.

12) Hardy, A.M., Allen J.R., Morgan, W.M. and Curran, J.W.: The incidence rate of acquired immunodeficiency syndrome in selected populations. J.A.M.A., 253: 215-220, 1985.

13) O'Duffy, J.F. and Isles, A.F.: Transfusion-induced AIDS in four premature babies. Lancet, ii : $1346,1984$.

14）片山 透：輸血後肝炎の発症状況．厚生省血液研 究事業, 昭和58年度研究報告集, 180-188, 1984.

15) Jaffe, E.R.: Erythrocyte metabolism and its relation to the liquid preservation of human blood. In : Clinical practice of blood transfusion (eds. Petz L.W. and Swisher, S.N.). Churchill Livingstone, New York, 1981, pp. 265-287.

16) Barnard, D.R., Chapman, R.G., Simmons, M.A. and Hathaway, W.E.: Blood for use in exchange transfusion in the newborn. Transfusion, $20: 401-408,1980$.

17) 榎 正行, 後藤良治, 後藤敦子, 石田 明, 谷田 部道夫, 東 音高, 上坂佳敬: 頻回の輸血により 生じた Graft-versus-Host Disease の 1 超未熟児 例。日新生児会誌, $21: 696-702,1985$. 